\title{
Rearing Theridion melanostictum O. P. Cambridge (Araneae: Theridiidae) on Tetranychus urticae Koch and larvae of Spodoptera littoralis Boisd.
}

\author{
Nahla A. I. Abd El-Azim \\ Plant Prot.. Res. Inst., Agri. Res. Center, Dokki, Giza, Egypt.
}

\begin{abstract}
Theridion melanostictum O. P. Cambridge, 1876 (Araneae: Theridiidae) was collected from apple trees, El- Sadat city, El-Menofia governorate. Reared under laboratory conditions of $24-26^{\circ} \mathrm{C}$ and $60-70 \%$ R.H., males reached maturity after 4 spiderlings (instars); while females after 5 (instars). Spiders were fed every two days on the two preys, Tetranychus urticae Koch and larvae of Spodoptera littoralis (Boisd.). Total spiderlings averaged (105 \pm 2 and $136.6 \pm 3),(51.1 \pm 1.6$ and $57.5 \pm 2.7)$ days for male and female when fed on T. urticae and $S$. littoralis, respectively. Life cycle, feeding behavior, food consumption and mating behavior were observed.
\end{abstract}

Key words: Theridion melanostictum, Theridiidae, Life cycle, feeding behavior, Tetranychus urticae, Spodoptera littoralis, Food consumption, Mating behavior.

\section{INTRODUCTION}

The family Theridiidae is one of the largest families of spiders including 24 species of 10 genera in Egypt (El-Hennawy, 2006) from 2420 species and 121 genera all over the world (Platnick, 2014).

The genus Theridion Walckenaer, as defined by Levi, 1957, 1959, 1963 is cosmopolitan and large as over 90 species have been recorded from North America alone, and many of its species are abundant in favorable habitats. But published knowledge of these species consists of little more than taxonomic descriptions and brief, scattered natural history observations (Kaston, 1981; Hanggi et al., 1995 \& Roberts, 1995).

The genus Theridion Walckenaer had 5 species till 2006 then another species, $T$. cairoense, was added in 2011 by Wunderlich. Finally, Thaler-Knoflach \& El-Hennawy in 2012, described other two species to be 8 species recorded of this genus till now in Egypt.

Theridion melanostictum was studied under laboratory conditions, $28^{\circ} \mathrm{C}$ and $70-80 \%$ R.H., by Abo-Taka et al., 2004 who studied its life cycle fed on the two spotted spider mites, Tetranychus urticae and the green aphid, Brevicoryne brassicae.

This study aims to use T. melanostictum on the larvae of Spodoptera littoralis which appears as the most danger pests distributing all over the fruit trees, field crops and vegetables plants comparing with the previous study by Abo-Taka et al., 2004 to through some light on its role to control this kind of pests.

\section{MATERIALS AND METHODS}

\section{A-Rearing the spiders:}

Six adult females of Theridion melanostictum Cambridge were collected on 16 December 2013 from apple trees, El- Sadat city, El-Menofia governorate, Egypt. It was reared individually inside a plastic vials, fed until laid egg sacs and observed till hatching. Every female laid an egg sac, the newly hatched spiderling were divided into two groups to feed on two preys Tetranychus urticae adult and Spodoptera littoralis $2^{\text {ndinstars }}$ larvae. Each spiderling was supplied with a known number of the prey and observed till reached maturity. These experiments were carried out in an incubator $24-26^{\circ} \mathrm{C}$ and $60-70 \%$ R.H. Spider individuals were examined every two days and the numbers of consumed prey individuals were recorded and replaced by another live one.

\section{B- Preys Rearing: \\ 1-Rearing of mite prey:}

The two-spotted spider mite $T$. urticae individuals were collected from heavily infested castor bean leaves and reared in the laboratory on sweet potato (Ipomoea batata Lam.) cuttings (twigs) with stems inserted in conical flask full of water and kept under laboratory conditions $\left(26 \pm 2^{\circ} \mathrm{C}\right.$ and $70 \pm 5 \%$ R.H.). Water was changed as needed.

\section{2- Rearing of insect prey:}

Cotton leaf warm $S$. littoralis was reared in the laboratory using a method described by Mostafa (1988). Field-collected egg batches of $S$. littoralis were cultured on castor bean leaves 
Ricinus communis L., in glass jars, $20 \mathrm{~cm}$ diameter by $15 \mathrm{~cm}$ height. The leaves were washed and cleaned. The jars were covered with muslin cloth held in position by rubber bands and kept in an incubator at $25^{\circ} \mathrm{C}$ and $60-70 \%$ R.H. The jărs were daily examined. Adult moths were confined in glass chimneys as oviposition cages and were provided with nerium leaves $(N$. oleander) as oviposition sites. These oviposition cages were provided with pieces of cotton soaked in $10 \%$ sugar solution for adult nourishment. The obtained eggs were re-cultured as mentioned above. The batches were left until hatch and the different larval instars were taken as introduced prey to the spider.

\section{RESULTS AND DISCUSSION}

\section{Egg sac, eggs and incubation period:}

The egg sac was spherical in shape, pale white and became dark before hatching; the eggs inside the egg sac were circle, white pale and also became dark before hatching. The incubation period of Theridion melanostictum eggs lasted after $24.5 \pm 1.2$ days for the females which fed on T. urticae; while it lasted after $11.3 \pm 1.8$ days for the females fed on $S$. littoralis. These result differed from that the results of Abo-Taka et al., 2004 fed the same species on $T$. urtiace but at $28 \pm 1^{\circ} \mathrm{C}$ and $60-70 \%$ R.H. This may be due to the difference in temperature.

\section{Spiderlings:}

During rearing the spiderlings in two groups, males reached maturity after 4 instars and 5 instars for females when fed on both previous preys during their development (Table 1) and this agree with Abo-Taka et al., 2004.

Total spiderlings lasted after $105 \pm 2$ and $136.6 \pm 3$ days for males and females, respectively when fed on $T$. urticae; while it lasted after $51.1 \pm 1.6$ and $57.5 \pm 2.7$ days for males and females, respectively when fed on $S$. littoralis.

The life cycle lasted after $129 \pm 2$ and $161 \pm 3$ days for males and females, respectively when fed on T. urticae; while it lasted after $62.4 \pm 1.6$ and $68.8 \pm 2.7$ days for males and females, respectively when fed on $S$. littoralis.

\section{Mating behavior:}

Mating behavior of a couple of male and female, T. melanostictum was observed. After inserting female in a glass container, male was introduced to her. The male then began the courtship process within 4 minutes. He started rubbing the two pedipalps by each other, then approached more towards her. Pedipalps of male came in contact with female's body that stopped movement and trying to reach her epigynum. After about 5 minutes, male inserted the left palpal organ about 10 minutes. Then, the male moved away from the female for a few minutes. After that, the male approached again and inserted his right palpal organ in her epigynum for about 10 minutes. After that, the male left the female and stopped in the other side of the glass container. These results agree with those Ahmed and Abd El- Maaboud, 2014 who studied the mating behavior of Theridion incanescens and Sallam, 2004 when reared Steatoda paykulliana (Theridiidae) but disagree with Abo-Taka et al., 2004 when reared T. melanostictum.

There are great variations in coloration and abdomen patterns of adult spiders especially in dorsal patterns as shown in (Figure 1), this variation may be refer to the kind of food or to the habitat locations and $i$ wish to clarify this in farther research.

Table (1) life cycle of Theridion melanostictum fed on, Tetranychus urticae adult and Spodoptera Littoralis instars larvae.

\begin{tabular}{|c|c|c|c|c|c|c|c|c|c|c|c|c|}
\hline \multirow{3}{*}{$\begin{array}{l}\text { Developmental } \\
\text { Stage }\end{array}$} & \multicolumn{6}{|c|}{ Tetranychus urticae } & \multicolumn{6}{|c|}{ Spodoptera littoralis } \\
\hline & \multicolumn{3}{|c|}{ Male } & \multicolumn{3}{|c|}{ Female } & \multicolumn{3}{|c|}{ Male } & \multicolumn{3}{|c|}{ Female } \\
\hline & Range & Mean & S.D. & Range & Mean & S.D. & Range & Mean & S.D. & Range & Mean & S.D. \\
\hline Incubation Period & $23-26$ & 24.5 & 1 & $21-27$ & 24.5 & 1.2 & $10-14$ & 11.25 & 1.876 & $10-14$ & 11.25 & 1.8 \\
\hline $1^{\text {st }}$. spiderling & $22-26$ & 25 & 0.9 & $23-26$ & 25 & 1.5 & $8-11$ & 9.8 & 0.8 & $23-26$ & 10 & 0.9 \\
\hline $2^{\text {nd }}$. Spiderling & $24-27$ & 24.7 & 1.1 & $25-29$ & 26 & 1.3 & $9-14$ & 11.9 & 0.8 & $25-29$ & 14 & 1.1 \\
\hline $3^{\text {nd }}$. Spiderling & $25-28$ & 26 & 1.1 & $26-32$ & 28 & 1.9 & $14-17$ & 14.3 & 0.7 & $26-32$ & 11 & 1.5 \\
\hline $4^{\text {th }}$. Spiderling & $27-30$ & 29 & 0.8 & $29-34$ & 31 & 1.5 & $12-17$ & 15 & 0.9 & $29-34$ & 12 & 1.5 \\
\hline $5^{\text {th }}$. Spiderling & - & - & - & $25-30$ & 27 & 1.4 & - & - & - & $25-30$ & 9.5 & 1 \\
\hline Total Spiderlings & $99-109$ & 105 & 2 & $130-142$ & 136.6 & 3 & $48-55$ & 51.1 & 1.6 & $54-64$ & 57.5 & 2.7 \\
\hline Life cycle & $123.5-133.5$ & 129 & 2 & $154.5-166.5$ & 161 & 3 & $59-66$ & 62.4 & 1.6 & $65-75$ & 68.8 & 2.7 \\
\hline
\end{tabular}


Table (2): Food consumption of Theridion melanostictum fed on, Tetranychus urticae adult and Spodoptera littoralis $2^{\text {nd }}$ instar larvae

\begin{tabular}{|c|c|c|c|c|c|c|c|c|c|c|c|c|}
\hline \multirow{3}{*}{$\begin{array}{l}\text { Developmental } \\
\text { stage }\end{array}$} & \multicolumn{6}{|c|}{ Tetranychus urticae } & \multicolumn{6}{|c|}{ Spodoptera littoralis } \\
\hline & \multicolumn{3}{|c|}{ Male } & \multicolumn{3}{|l|}{ Female } & \multicolumn{3}{|c|}{ Male } & \multicolumn{3}{|l|}{ Female } \\
\hline & Range & Mean & S.D. & Range & Mean & S.D. & Range & Mean & S.D. & Range & Mean & S.D. \\
\hline $1^{\text {st }}$. spiderling & $200-210$ & 200 & 1.89 & $240-253$ & 240 & 2 & 14-19 & 18.15 & 1.57 & $16-22$ & 19.25 & 1.7 \\
\hline $2^{\text {nd }}$. Spiderling & $238-250$ & 250 & 1.62 & $260-272$ & 260 & 1.81 & $20-25$ & 20.3 & 1.12 & $25-31$ & 25.38 & 1.5 \\
\hline $3^{\text {nd }}$. Spiderling & $250-264$ & 250 & 1.89 & $280-294$ & 280 & 2.1 & $28-32$ & 28.2 & 0.89 & $30-36$ & 30.38 & 1.5 \\
\hline $4^{\text {th }}$. Spiderling & $270-283$ & 270 & 1.75 & $280-287$ & 280 & 1.1 & $33-40$ & 33.35 & 1.57 & $35-42$ & 35.44 & 1.8 \\
\hline $5^{\text {th }}$. Spiderling & - & - & - & $284-290$ & 284 & 0.9 & - & - & - & $38-45$ & 39.2 & 1.7 \\
\hline otal spiderling instar & $958-997$ & 971 & 4.4 & $\begin{array}{r}1104- \\
1384 \\
\end{array}$ & 1340 & 36.9 & $95-116$ & 100 & 4.08 & $144-170$ & 150 & 5.9 \\
\hline
\end{tabular}
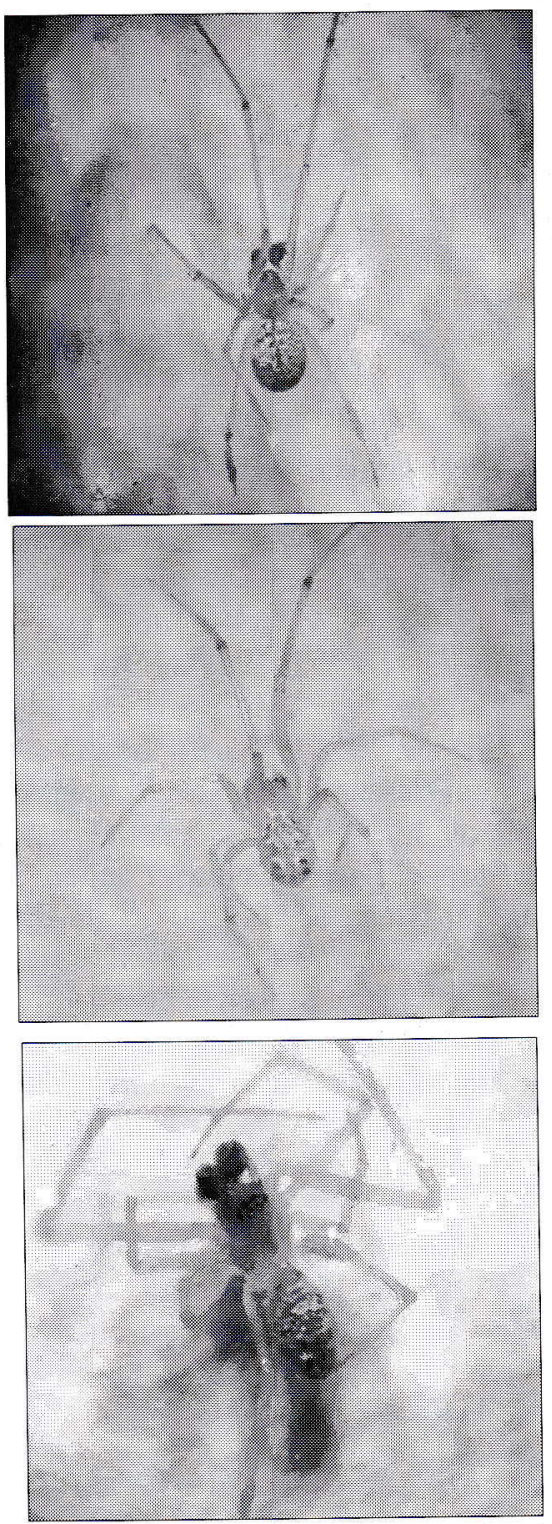

Adult Male
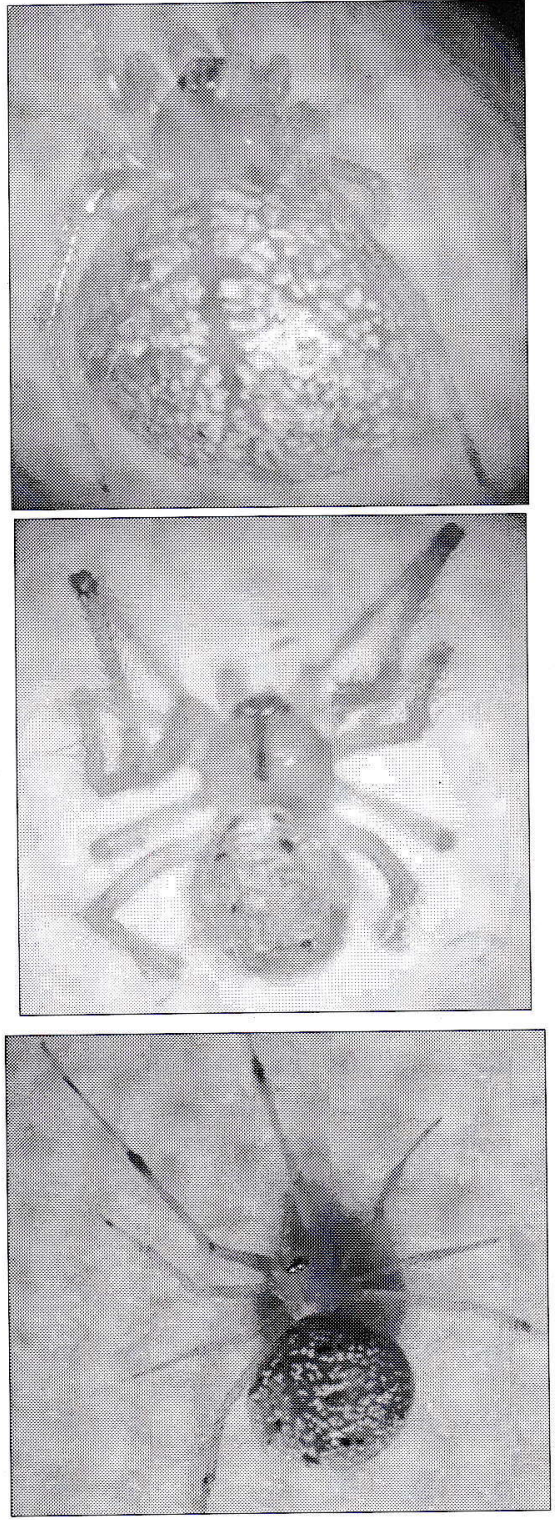

Adult Female

Fig. (1). 


\section{Feeding behavior:}

The spider attacked the T. urticae mite from the anterior part of the body and turned the prey more than once before sucking its body contents while attacked $S$. littoralis larva from the inter-secutar membrane between head and thorax, then sucked its contents.

\section{Food consumption:}

During the study of food consumption of spider $T$. melanostictum, different spiderling instars and adults were fed on $T$. urticae adult and $S$. littoralis 2 nd instar larvae (Table 2).

The mean total number of consumed individuals was $971 \pm 4.4$ and $1340 \pm 36.9$ individuals for the total spiderlings of male and female respectively when fed on T. urticae, and $100 \pm 4.08$ and $150 \pm 5.9$ individuals for the total spiderlings of males and females, respectively when fed on $S$. littoralis $2^{\text {nd }}$ instar larvae.

Average numbers of consumed preys per female were more than those of males; and this was observed for $T$. urticae and $S$. littoralis which gradually increased during the fourth, fifth and adult spider stages (Table 2).

\section{ACKNOWLEDGMENTS}

The authoress is indebted to Col. Hisham K. ElHennawy (Arachnid Collection of Egypt, Cairo) who identified the spider species and kindly revised a draft of the manuscript.

The authoress extends her gratitude to Dr. Gihan sallam, senior researcher, Plant Protection Research Institute, for her generous help during carrying out this work.

\section{REFERENCES}

Abo-Taka, Safaa M.; Hussein, A. M.; Osman, A. A.; Zohdi, G.I. and Hamada, E.G.I., 2004. Studies on Some biological aspects of Theridion melanostictum O.P. Cambridge, 1876 (Arachnida: Araneida). Serket, 9(1): 5-9.

Ahmad, Naglaa. F. R., and Akram S. Abd El-
Maaboud, 2014. Biological aspects of the spider Theridion incanescens (Araneae:Theridiidae) feeding on Tetranychus urticae and Ceratitis capitata with notes on its mating behavior. Egypt. Acad. J. Biolog. Sci., 7(2): 9-14.

El-Hennawy, H. K. 2006. A list of Egyptian spiders (revised in 2006). Serket, 10(2): 65-76.

Hanggi, A.; Stockli, E. and Nentwig, W. 1995. Habitats of central European spiders. Miscellanea Faunistica Helvetiae, 4: 459 pp.

Kaston, B.J. 1981. Spiders of Connecticut. Rev. ed. State Geological and Natural History Survey of Connecticut, Bulletin No. 70.

Levi, H.W. 1957. The spider genera Enoplognatha,Theridion, and Paidisca in America north of Mexico (Araneae, Theridiidae). Bulletin of the American Museum of Natural History 112: 1- 123.

Levi, H.W. 1959. The spider genera Achaearanea, Theridion and Sphyrotinus from Mexico, Central America and the West Indies (Araneae, Theridiidae). Bulletin of the Museum of Comparative Zoology, 121(3):57-163.

Levi, H.W. 1963. American spiders of the genus Theridion, Araneae, Theridiidae). Bulletin of the Museum of Comparative Zoology, 129(10): 481589.

Mostafa, S. A. 1988. Effect of some insect growth regulators on some cotton pests. M. Sc. Thesis, Fac. Agric., Al- Azhar Univ. Egypt, 100pp.

Platnick, N. I. 2014. The world spider catalog, Version 15. American Museum of Natural History, online at http://research.amnh.org/iz/spiders/catalog.

Roberts, M.J. 1995. Spiders of Britain and Northern Europe. Harper Collins, London. 383pp.

Sallam, Gihan M. E. 2004. Life cycle of Steatoda paykulliana (Walckenaer, 1805) in Egypt (Araneidae). Serket, 9(2): 37-40.

Thaler-Knoflach, B. and El-Hennawy, H. K. 2012. Theridion incanescens Simon, 1890 and Theridion jordanense Levy \& Amitai, 1982 new to the fauna of Egypt (Araneae: Theridiidae). Serket, 13(1/2): 91- 98.

Wunderlich, J. 2011. Extant and fossil spiders (Araneae). Beitr. Araneol., 6: 1-640. 